\title{
Czołgi Orientu. Azja w strategiach Command \& Conquer w świetle teorii postkolonialnej
}

Szymon Piotr Kukulak 


\section{Czołgi Orientu. Azja w strategiach Command \& Conquer w świetle teorii postkolonialnej}

Szymon Piotr Kukulak

TEKSTY DRUGIE 2017, NR 3, S. 294-320

DOI: $10.18318 / \mathrm{td} .2017 .3 .18$

\section{Wstęp. Orient, którego nie było podwójnie}

Próby spojrzenia na gry komputerowe z perspektywy postkolonialnej' podejmowano już w odniesieniu do wielu gatunków (np. FPS-ów) ${ }^{2}$, lecz inne - jak strategie czasu rzeczywistego - wciąż nie doczekały się zadowalającego opracowania. Głównym tego powodem wydaje się kwestia wyboru pola badań - część analiz koncentruje się na sposobie portretowania konkretnych grup lub regionów (np. świata arabskiego), ale nie podejmuje

1 W literaturze zastrzega się, że w przypadku badania gier komputerowych postkolonializm można dyskutować tylko w znaczeniu wąskim, tj. jako refleksję nad dziedzictwem kolonializmu. Zob. S. Lammes Postcolonial Playgrounds: Games as postcolonial cultures, „Eludamos. Journal for Computer Game Culture" 2010 No. 4, s. 2; tejże Spatial regimes of the digital playground: cultural functions of spatial identification in post-colonial computer games, w: Gaming realities. A challenge for digital culture, ed. by M. Santorineos, FOURNOS Centre for the Digital Culture, Athens 2006, s. 241.0

2 Zob. J. Höglund Electronic Empire: Orientalism Revisited in the Military Shooter, "Game Studies” 2008 No. 1.
Szymon Piotr Kuku-

lak - mgr, doktorant na Wydziale Polonistyki UJ. Zajmuje się przenikaniem popkultury ze sferą naukowo-technologiczną w obszarze literatury (szczególnie fantastyki naukowej) i gier komputerowych. Ostatnio publikował teksty poświęcone Xavrasowi Wyżrynowi Jacka Dukaja, ewolucji literackich i filmowych wizji postapokaliptycznych w kontekście rozwoju broni nuklearnej oraz roli realnych odkryć z zakresu fizyki neutronowej dla kształtu dwóch powieści Stanisława Lema. 
dyskusji na temat ogólnych mechanizmów konstrukcji Innego, często działających podobnie w odniesieniu do innych portretowanych mniejszości, narodów czy krajów ${ }^{3}$. Inne ograniczenia wynikają z wyboru przedmiotu badań, gdyż prace przekrojowe często zestawiają ze sobą gry wideo odmiennych typów, pomijając problemy związane ze specyfiką gatunkową - z kolei analizy o charakterze studium przypadku są zwykle bardziej wnikliwe, ale rzadziej próbują uogólniać stawiane diagnozy na całość danego gatunku.

Rozsądnym punktem wyjścia przy próbie stworzenia całościowego opisu gatunku wydaje się analiza cyklu przez lata w nim wiodącego - Command $\odot$ Conquer ${ }^{4}$. Na mocy szablonu, który właśnie ta seria stworzyła (wraz z pierwszymi dwiema częściami cyklu WarCraft), RTS-y we wczesnym okresie rozwoju najczęściej portretowały wojny dwustronne, gdzie obie cyfrowe armie silne polaryzowano pod względem etycznym - co istotne, armie "złe" często orientalizowano. Mechanizm ten daje się opisywać w odniesieniu do cyklu Blizzarda tylko ogólnie, wskutek osadzenia gier w uniwersum fantastycznym - podobnie jest z Dune II ${ }^{5}$, od którego cały gatunek się historycznie wywodzi. Gry Command $\odot$ Conquer mogą jednak stanowić przedmiot analizy bardziej szczegółowej, gdyż konstruują antagonistów na bazie realnych sił czy mocarstw XX-wiecznej Azji, a przy tym operują konwencją historii alternatywnej - nie tylko portretując realny Wschód zgodnie z perspektywą zachodnią, ale i zgodnie z nią właśnie go deformując, demaskując w dwójnasób niedoskonałości użytej soczewki, wiodące często do rozmaitych sprzeczności.

Każda z trzech podserii Command $\odot$ Conquer wprowadza innego antagonistę tego typu. Dwie z nich - tzw. cykl tyberiański i Generals ${ }^{\mathbf{6}}$ - toczą się w świecie, gdzie Zachodowi zagraża fikcyjna, międzynarodowa grupa terrorystów o orientalnej specyfice: odpowiednio, Bractwo Nod i Armia Wyzwolenia Globalnego (GLA). Wojny sportretowane w obu cyklach w planie fabularnym nawiązują do konfliktów tzw. czwartej generacji, Zachodowi przeciwstawiając ponadnarodowy fundamentalizm Trzeciego Świata. Jedynie trzeci cykl

3 Przykładem mogą być prace Vita Sislera nt. przedstawień Bliskiego Wschodu w grach różnych gatunków. Zob. V. Sisler Digital Arabs: Representation in Video Games, „European Journal of Cultural Studies" 2008 No. 2.

4 Poza zasięg analizy wyłączono tu gry niewydane na PC lub niebędące RTS-ami, m.in. C\&C: Renegade (FPS), C\&C4: Tiberium Twilight (klasyfikowany jako RTT) czy C\&C: Tiberium Alliances (strategia przeglądarkowa). Westwood Studios, Dune II. The Building of a Dynasty, Virgin Interactive 1992.

6 EA Games Command \& Conquer: Generals, Electronic Arts 2003. 
w obrębie gier Command $\partial$ Conquer, trylogia Red Alert, ma odmienną specyfikę - opowiada alternatywną historię ostatniego półwiecza, zastępując zimną wojnę trzema sukcesywnymi konfliktami „gorącymi”. W dwóch pierwszych częściach tej podserii agresorem jest Związek Sowiecki, zaś w Red Alert 3 powstałej na przełomie mileniów, gdy w RTS-ach standardem stały się konflikty multilateralne - agresorem uczyniono Japonię, dodaną do uniwersum jako mocarstwo równorzędne wobec USA i ZSRR. Analogiczną rolę pełni w Generals sojusznik Ameryki w wojnie z GLA - Chińska Republika Ludowa. Te trzy mocarstwa - Chiny (u Saida będące częścią „nowego" Orientu'), Japonia (do której tezy Saida także bywają aplikowane ${ }^{8}$ ) i ZSRR (sportretowany w $C \partial C$ jako kraj azjatycki raczej niż europejski $\left.{ }^{9}\right)$ - stanowią alternatywne wersje państw realnych, lecz ich obraz zniekształcono podług zachodnich stereotypów. Poniżej opisano sposoby orientalizacji wyliczonych pięciu potęg azjatyckich w poszczególnych uniwersach - dwóch grup terrorystycznych i trzech mocarstw - z odniesieniem do kilku płaszczyzn, na jakich proces ów dokonuje się równolegle.

\section{Mechanizmy orientalizacji wschodnich armii w RTS-ach}

Elliott i Kapell postulują użycie do analizy gier historycznych trójpoziomowego modelu Espena Aarsetha, zakładającego rozdzielność gry - jej fabularnej zawartości, zasad i celów rozgrywki ${ }^{10}$. Przez wzgląd na konwencję historii alternatywnej opisywanych tu RTS-ów ten trójdzielny model wydaje się odpowiedni do ich analizy, lecz dostosowano go do specyfiki gatunkowejpozwalającej utożsamić badane poziomy z trzema poziomami fabuły ${ }^{11}$. Opis świata gry zawężono tu do opisu ram konfliktu sportretowanego w danej grze

7 E.W. Said Orientalizm, przeł. M. Wyrwas-Wiśniewska, Zysk i S-ka, Poznań 2005, s. 101.

8 Zob. D. Nishihara Said, Orientalism, and Japan, "Alif: Journal of Comparative Poetics” 2005 No. 1.

9 Przykładem łańcuch "syberyjskich” misji ZSRR w rozszerzeniu pierwszej części cyklu, eksponujący azjatycką scenerię. Zob. Westwood Studios, Command \& Conquer: Red Alert. Counterstrike, Virgin Interactive 1997.

10 A. Elliott, M.W. Kapell Introduction: To Build a Past that Will "Stand the Test of Time": Discovering Historical Facts, Assembling Historical Narratives, w: Playing the Past. Digital Games and the Simulation of History, red. A. Elliott, M.W. Kapell, Bloomsbury Academic, London 2013, s. 10.

11 Więcej o stosowanej tu modyfikacji modelu Kapella w: S.P. Kukulak Generał bez właściwości. Rola etyki i technologii wojennych w kształtowaniu tożsamości postaci gracza w RTS-ach, "Homo Ludens" $2015 \mathrm{nr} 2$ (8). 
na poziomie całych kampanii dla pojedynczego gracza. Cele stawiane przed graczem - utożsamiono z celami poszczególnych misji, z jakich kampania się składa. Wreszcie, rozbieżności w zakresie zasad gry dla poszczególnych stron konfliktu w RTS-ach manifestują się przede wszystkim odmiennością arsenałów, jakie zostały przypisane do poszczególnych wirtualnych armii w celu wymuszenia na graczu użycia odmiennej taktyki w toku pojedynczych potyczek (najniższy poziom fabularny). Orientalizacja armii wschodnich przebiega w nieco odmienny sposób na każdym z tych trzech poziomów: kampanii, misji i poszczególnych starć.

Na poziomie kampanii ramy fabularne niemal każdej z opisywanych gier tworzy inwazja „złej” strony - czyli tej wschodniej (terrorystów lub mocarstw) - na terytoria zachodnie lub neutralne, czemu strona „dobra" musi przeciwdziałać, starając się przywrócić status quo ante. Wizja ta ogólnie nawiązuje do tradycyjnego postrzegania Wschodu jako niezmierzonych przestrzeni, skąd naciaggają kolejne fale najeźdźców ${ }^{12}$. Inwazje te w pięciu opisywanych seriach różni głównie dobór areny podboju, określający bazę możliwych odniesień do rzeczywistości - kluczowy staje się temat map, eksponowany w licznych pracach, poświęconych postkolonialnej analizie komputerowych gier strategicznych. Prace te wskazują często na kolonialne użycie map w grach strategicznych (odkrywanie i zawłaszczanie przestrzeni) i choć najczęściej przywołuje się tu tzw. minimapy ${ }^{13}$, pozwalające graczowi monitorować pole walki w toku danej misji, ten sam sposób podejścia do przestrzeni gry cechuje w równym stopniu mapy strategiczne na szczeblu kampanii. We wczesnych RTS-ach zadaniem tych map było z reguły dać graczowi wyobrażenie nie tylko o teatrze działań, ale i o postępach jego frakcji w rywalizacji o ziemię - jawnie kolonialnej. To obecne już w Dune II rozwiązanie skopiował tak WarCraft ${ }^{14}$, pustynne prowincje Arrakis zastępujący krainami Azeroth, jak i Tiberian Dawn ${ }^{15}$ oraz później Red Alert ${ }^{\mathbf{1 6}}$ - pierwsze gry podserii tyberiańskiej i zimnowojennej

Zob. E.W. Said Orientalizm, s. 414.

Zob. S. Lammes Spatial regimes of the digital playground..., s. 241; tejże Postcolonial Playgrounds..., s. 3; tejże Terra incognita. Computergames, cartography and spatial stories, w: Digital material: tracing new media in everyday life and technology, red. M. van den Boomen, S. Lammes, A. Lehmann, J. Raessens, M. Schaefer, Amsterdam University Press, Amsterdam 2009, s. 229.

Blizzard Entertainment, WarCraft: Orcs \& Humans, Interplay Entertainment 1994.

Westwood Studios, Command \& Conquer, Virgin Interactive 1995. Stosowany w artykule podtytuł (Tiberian Dawn) został przydany grze retroaktywnie w toku rozrostu serii.

Westwood Studios, Command \& Conquer: Red Alert. Virgin Interactive 1997. 
$C \partial C$ - stosujące już realne mapy polityczne odpowiednich regionów ${ }^{17}$ (jak wcześniej czyniły niektóre strategie turowe). Geograficzny aspekt kampanii pięciu opisanych sił - wraz z ogólnymi celami, jakie im przyświecają - wyznacza ramy dla możliwych odniesień do rzeczywistych krajów czy organizacji.

Orientalizacja na poziomie celów misji sprowadza się do zarezerwowania zadań o charakterze negatywnym, które fabularnie wiążą się z „orientalną" mentalnością danej armii, właśnie dla kampanii pięciu wschodnich sił. Wśród zadań niegodziwych - jak kradzieże czy zabójstwa - poczesne miejsce zajmuje tłumienie rebelii, jako wynikających z rzekomo typowej dla Orientu zdradliwości ${ }^{18} \mathrm{i}$ braku samoorganizacji ${ }^{19}$. Bunty są zarazem „dyżurnym" tematem dodatków do opisywanych gier, pozwalając na przedłużenie ich fabuły w sposób niekolidujący z finałem „właściwej” wojny.

Wreszcie każda ze stron charakteryzowana jest poprzez dobór unikalnych dla siebie jednostek (tj. typów dostępnych formacji wojskowych), z reguły: fikcyjnych w grach fantastycznych, lecz w grach historycznych - zaczerpniętych ze świata realnego. Formuła historii alternatywnej w grach $C \partial C$ owocuje rozwiązaniem hybrydowym - część wehikułów jest fantastyczna, część realna. Swoboda kreacyjna w obrębie pierwszej grupy pozwala modelować daną armię podług oczekiwań odbiorcy, ale i w drugim przypadku dochodzi do szeregu manipulacji - na dwóch płaszczyznach: wyboru jednostek wzorcowych i sposobu ich odwzorowania w grze.

W sferze doboru realnych pierwowzorów dla cyfrowych wojsk, pole do manipulacji otwiera przede wszystkim luźne podejście do historii wojskowości, jakie cechuje $C \partial C$. Seria wprawdzie sięga do rezerwuaru czołgów czy samolotów ostatniego półwiecza, ale obie strony obdarowuje maszynami pochodzącymi z różnych epok (np. w Red Alert amerykańskim śmigłowcom Apache Longbow z lat 8o. towarzyszą sowieckie myśliwce Jak-9 z lat 40.). Pozwala to stworzyć iluzję zaawansowania lub zacofania technicznego danej armii na danym polu - zaś o tym, która armia winna być silniejsza $w$ danym typie broni, decydują stereotypy (stworzone zwykle na podstawie wyobrażeń na temat różnych okresów zimnej wojny).

Drugie pole do manipulacji związanych z selekcją realnych wzorów dla wirtualnego sprzętu bojowego otwiera charakterystyczna dla większości RTS-ów

Późniejsze gry w trzech cyklach podawały wciąż lokalizacje misji, ale unikały wizualizacji granic.

E.W. Said Orientalizm, s. 395.

Tamże, s. 70. 
konieczność maksymalnej symplifikacji i dywersyfikacji cyfrowych arsenałów. Konieczność selekcji ledwie kilkunastu typów broni spośród realnego parku maszynowego danego mocarstwa skłania oczywiście do wyboru jej rodzajów najbardziej ikonicznych - pod uwagę biorąc zarówno obecność w popkulturze, jak i przystawalność do wachlarza strategii, jakie zaprojektowano dla każdej ze stron. Różnorodność rozgrywki wymaga, aby te ostatnie maksymalnie zdywersyfikować (wybór różnych stron powinien zmuszać do przyjęcia odmiennego stylu gry - poprzez udostępnienie graczowi odmiennych jednostek, różnych od siebie nie tylko wizualnie, ale i funkcjonalnie). Także o kształcie tej dywersyfikacji decydują najczęściej kulturowe stereotypy.

Trzecim ważnym czynnikiem w modelowaniu wschodnich arsenałów jest kompromis między wiernością odwzorowania realnych wehikułów $\mathrm{i}$ koniecznością zbalansowania poszczególnych armii, nieunikniony w strategiach historycznych ${ }^{20}$. Zbalansowanie arsenałów we wszystkich trzech podseriach COC jednak nie odbywa się przypadkowo - lecz tak, aby stosunek parametrów jednostek wschodnich do zachodnich (siły ognia, wytrzymałości, ceny) również odzwierciedlał zachodni sposób postrzegania Orientu.

\section{Terroryści bliskowschodni w $\boldsymbol{C} \& \boldsymbol{C}$. Islamiści bez islamu}

Opisane wyżej ogólne mechanizmy orientalizacji armii Wschodu w RTS-ach w $C \odot C$ przyjmują inny kształt w przypadku alternatywnych wersji realnych azjatyckich mocarstw, inny zaś w odniesieniu do fikcyjnych organizacji terrorystycznych. Zaczynając od tych drugich, perspektywę wyższościową wyraźnie widać już w sposobie konstrukcji ram konfliktu, jakie organizują fabułę najstarszej podserii gier Command $\otimes$ Conquer, cyklu tyberiańskiego - obejmującego Tiberian Dawn, Tiberian Sun ${ }^{21}$ i Tiberium Wars $^{22}$. Utrzymane w poetyce SF gry pozwalają dowodzić albo międzynarodowymi siłami ONZ (zwanymi GDI, ang. Global Defense Initiative), albo armią religijnych terrorystów ze wspomnianego Bractwa Nod. Fabuła cyklu wychodzi od alternatywnego obrazu bliskiej przyszłości, gdzie Bractwo przejmuje władzę w kolejnych krajach Trzeciego Świata, dzięki zyskom z eksploatacji złóż toksycznego minerału zwanego

20 porównywalna liczba graczy wybierała każdą ze stron konfliktu, toteż mechanika gry nie może faworyzować żadnej z nich.

Westwood Studios, Command \& Conquer: Tiberian Sun, Electronic Arts 1999.

EA Los Angeles, Command \& Conquer 3: Tiberium Wars, Electronic Arts 2007. 
tyberium, zarastających powoli Ziemię od czasu upadku we Włoszech pod koniec XX wieku tajemniczego meteorytu. Impakt stanowi dla uniwersum tyberiańskiego punkt dywergencji. Jest on niezbędny dla zaistnienia globalnego zagrożenia, sugerując, że Wschód z Zachodem nie mógłby konkurować sam z siebie - pozwala mu na to "niezasłużony” dostęp do cudownych złóż (tyberium stanowi tu ekwiwalent ropy naftowej) i lider o zachodniej umysłowości - biały mężczyzna, pragmatyczny Kane (lider lokalny, więc autentycznie irracjonalny, nie mógłby być równie skuteczny - co pokazuje fabuła sequeli). Bractwo stanowi zatem spadkobiercę nie tylko szeregu realnych organizacji terrorystycznych, ale i obrazu chciwego szejka, jaki zaczął krążyć w zachodniej popkulturze za sprawą pierwszego kryzysu naftowego w latach $70 .^{23}$

W uniwersum równoległym do tyberiańskiego, ograniczonego jak dotąd do Command $\odot$ Conquer: Generals, rolę analogiczną do Bractwa pełni wspomniana GLA, jako grupa antagonistyczna wobec mocarstw „cywilizowanych". Choć to uniwersum naszkicowano grubszą kreską, główną różnicę między GLA i jej realnymi wzorami (wśród których najbardziej oczywistym była w czasie premiery gry Al-Kaida, co podkreśla już wybór wąglika na „flagową" broń terrorystów w grze ${ }^{24}$ ) wydaje się świecki charakter organizacji - efekt unikania w grze referencji do islamu. Graczowi sugeruje się wręcz, że sukcesy Armii - nieosiągalne dla realnych ugrupowań tego typu - są częściowo przynajmniej związane z przyjęciem przezeń ideologii świeckiej, więc niejako „nowocześniejszej” od islamskiego fundamentalizmu. Fikcyjna ideologia (detale wskazują na arabski socjalizm) wydaje się implikować bardziej racjonalny modus operandi, czyniąc GLA większym zagrożeniem dla zachodnich interesów od realnych dżihadystów - pomimo że to właśnie do nich gra odsyła $\mathrm{w}$ warstwie wizualnej (co wynika z przyjęcia poetyki realistycznej - niejako w opozycji do cyklu tyberiańskiego, który odszedł odeń po Tiberian Dawn). Sam kształt obu uniwersów dowodzi już zatem przyjęcia przez twórców wyższościowej perspektywy, co znajduje odzwierciedlenie na poszczególnych płaszczyznach odpowiednich gier: kampanii, misji i arsenałów.

\subsection{Kampanie bliskowschodnie. Orient poza Orientem}

Jak wspomniano, kluczowy dla charakteru inwazji odmalowanych w grach Cə C jest wybór ich areny, definiujący przestrzeń skojarzeniową dla wydarzeń

23 E.W. Said Orientalizm, s. 394.

24 J. Zdanowski Historia Bliskiego Wschodu wXX wieku, Ossolineum, Wrocław 2010, s. 493. 
w świecie gry. Właśnie teren działań obu grup terrorystów wiąże je najsilniej $\mathrm{z}$ realnymi organizacjami, pozwalając graczowi wypełnić luki w obrazie alternatywnego świata. W obu przypadkach jedną z konsekwencji tabuizacji islamu jest zaskakujące z pozoru unikanie portretowania Bliskiego Wschodu - poprzez "wypchnięcie” fabuł kolejnych gier poza Azję Zachodnią. Już w Tiberian Dawn ${ }^{25}$ przyjęto dwa takie „zastępcze” teatry operacyjne: w kampanii GDI jest to Europa, której wschodnią część postać gracza zastaje w rękach terrorystów, a w kampanii Nod - Afryka, którą należy w imieniu Bractwa „wyzwolić” z ucisku neokolonialnego. W obu przypadkach zarówno początkowy rozkład kontrolowanych przez obie strony terenów, jak i sposób przemieszczenia się frontu wraz z postępami gracza mówi wiele o realnych pierwowzorach GDI i Nod - i o specyficznym sposobie postrzegania obu tych kontynentów z perspektywy Ameryki (syndrom często diagnozowany w odniesieniu do strategii $\left.{ }^{26}\right)$, który zaważył na kształcie fabuły Tiberian Dawn, owocując wieloma niespójnościami i błędnymi uogólnieniami.

W pierwszej części cyklu tyberiańskiego, w Europie granica terytoriów GDI i Nod odpowiada niedawnemu przebiegowi żelaznej kurtyny, co tę pierwszą organizację każe postrzegać nie jako militarną emanację wspólnoty międzynarodowej (jak głosi fabuła), ale samej cywilizacji zachodniej. Kolejność, w jakiej postać gracza wydziera terrorystom kraje Europy Wschodniej - poczynając od republik bałtyckich, przez Polskę i Czechy, kończąc na Bałkanach - odpowiada natomiast sekwencji, w jakiej niedawne demoludy były w latach 90. przyjmowane do realnych zachodnich struktur gospodarczych i wojskowych. Głównymi krajami, kontrolowanymi przez GDI na początku kampanii afrykańskiej Nod, są natomiast Egipt i RPA, realnie będące zachodnimi bastionami (Kair - od czasów Sadata ${ }^{27}$, Pretoria - do końca ery apartheidu, który zbiegł się w czasie z premierą gry ${ }^{28}$ ). Państwem, z którego gracz rozpoczyna podbój kontynentu, jest antyzachodnia Libia (podówczas pod rządami Kadafiego, także głoszącego hasła panarabskie i oskarżanego od od równika. B. Davidson Społeczna i polityczna historia Afryki w XX wieku, przeł. B. Hlebowicz, Wydawnictwo Naukowe PWN, Warszawa 2011, s. 167. 
lat 80. o wspieranie terroryzmu $\left.{ }^{29}\right)$. Kierunek ,jednoczenia” Afryki pod władzą Nod - poczynając od brzegów Morza Śródziemnego, przez Afrykę Subsaharyjską, ku Przylądkowi Dobrej Nadziei - odpowiada kolejności, w jakiej autonomizowały się afrykańskie kolonie, i zarazem kierunkowi terytorialnego rozrostu Organizacji Jedności Afrykańskiej ${ }^{30}$. RPA, podbijana w finale kampanii przez postać gracza, dołączyła do OJA ${ }^{31}$ - na rok przed premiera gry - jako ostatni kraj kontynentu, co znajduje odbicie we wkroczeniu wojsk Bractwa do Kapsztadu, które w Tiberian Dawn stanowi zwieńczenie procesu „wyzwalania” Afryki.

Wyliczone zbieżności na pierwszy rzut oka przydają fabule realizmu, czyniąc z kampanii GDI niejako alegorię realnej okcydentalizacji Europy Wschodniej, z kampanii Nod zaś - swoisty retelling dekolonizacji Afryki, gdzie stawką jest wyzwolenie od ucisku już neokolonialnego. Paradoks polega na tym, że obie te narracje kolidują ze sobą - gdyby bowiem polityczne zakusy Nod w Europie ograniczyć do terenów byłego Imperium Osmańskiego (tradycyjnie z Orientem utożsamianego ${ }^{32}$ ), za filar ich unifikacji mógłby uchodzić albo islam, albo jego fikcyjna mutacja - gdyż Bractwo było w oczywisty sposób inspirowane Hamasem czy Hezbollahem, zaś instrukcja do gry wiąże je explicite z egipskim Islamskim Dżihadem ${ }^{33}$ (prowadzącym wówczas otwartą wojnę z władzami w Kairze ${ }^{34}$ i związanym z Bractwem Muzułmańskim ${ }^{35}$, być może dla Bractwa Nod eponimicznym). Bałkanizacja republik bałtyckich czy realnych krajów Grupy Wyszehradzkiej, które w grze do „osmańskich” ziem Nod zostają niejako „doklejone”, uniemożliwia jednak wykorzystanie islamu jako religii unifikującej europejskie dominia Kane'a - stąd potrzeba wprowadzenia kultu fikcyjnego, możliwego do przyjęcia też dla chrześcijan, jak sugerują odniesienia do Księgi Rodzaju (nazwa Bractwa czy imię lidera). Choć koncepcja terroryzmu religijnego, związanego z „hybrydowymi” apoka-

29

Tamże, s. 120.

Tamże, s. 242.

Tamże, s. 171.

E.W. Said Orientalizm, s. 308.

Poza zachodnimi grupami, jak aktywna wciąż IRA (grę wydano przed porozumieniem wielkopiątkowym) i United We Stand America (populistyczny ruch popierający Rossa Perota w wyborach prezydenckich $w 1992$ roku).

4 J. Zdanowski Historia Bliskiego Wschodu..., s. 368.

Tamże, s. 262. 
liptycznymi kultami, nie jest czysto fikcyjna (w 1995 roku Najwyższa Prawda dokonała zamachu w tokijskim metrze z użyciem sarinu ${ }^{36}$ ), synkretyzm kultu Nod jest w efekcie tak problematyczny, że uniemożliwia konkretyzację jego doktryny - gracz przez całą serię nie poznaje nawet zarysu dogmatyki Bractwa, naprzemiennie karmiony zamiast tego odniesieniami do obu religii wzorcowych ${ }^{37}$.

Decyzję o bałkanizacji Europy Wschodniej w Tiberian Dawn wydaje się dodatkowo tłumaczyć kierunek europejskiej konkwisty GDI - okazuje się bowiem, że europejska kwatera główna Nod jest położona w Sarajewie, realnie szturmowanym przez Serbów w chwili wydania gry (wbrew zbrojnym wysiłkom $\mathrm{NATO}^{38}$, w czym widać analogie do fikcyjnej interwencji GDI). Paralela serbska (kontynuowana w sequelach ${ }^{39}$, co potwierdza jej intencjonalność) samym swoim istnieniem sugeruje niedojrzałość Europy Wschodniej, która po 1991 roku - wolna od rzekomo stabilizującego ją uścisku Moskwy - rzekomo mogłaby się pogrążyć w chaosie bratobójczej wojny równie łatwo, jak uczyniły to republiki byłej Jugosławii, gdy osłabł uścisk Belgradu. Wojna w Bośni nie jawi się tu jako rezultat partykularnych napięć etnicznych (nie w każdym kraju postkomunistycznym obecnych), ale jako efekt cywilizacyjnej niższości „wschodnich” narodów (niedojrzałych i do demokracji nienawykłych), charakteryzującej - w takim obrazie rzeczywistości - całość „zewnętrznego imperium" Moskwy.

To fałszywe uogólnienie jest jedynie przykładem, jak synkretyczną naturę ma Bractwo Nod - pomyślane jako zbrojna reprezentacja Trzeciego Świata nie w całej jego złożoności, ale przeciwnie: jako jego swoiste uśrednienie, wymagające kulturowej homogenizacji, jakiej bez przekłamań osiągnąć nie sposób. Widać to równie wyraźnie podczas podboju Afryki, która u kresu dekolonizacji jawi się w grze - wedle tej samej logiki, którą zastosowano

36

D.E. Hoffmann Dead Hand. Reagan, Gorbachev and the untold story of the Cold War arms race, Icon Books, London 2010, s. 482.

Przykładem jest tytulatura: Bractwo w Tiberian Dawn ma nieformalną strukturę, stricte wojskową zyskuje w Tiberian Sun; tę zaś Tiberium Wars uzupełnia hierarchia religijna na wzór katolicki (w Kane's Wrath pojawia się "brat Marcjon” i "siostra Alexa”, tytułowana „przeoryszą"). Sam Kane tytułowany jest przez podkomendnych naprzemiennie "Mesjaszem" i „Prorokiem”.

8 Zob. W.J. Boyne Skrzydła wojny, przeł. J. Złotnicki, Wydawnictwo Wołoszański, Warszawa 2011, S. 424 .

Protagonistą kampanii Nod w Tiberian Sun jest serbski terrorysta Anton Slavik (zniekształcone "Slavić"), szef gwardii Nod zwanej Czarną Ręką (zaś jeszcze w Tiberian Dawn Kane'a porównuje się do Gawriły Principa). 
już w odniesieniu do Europy Wschodniej - mozaiką krajów niesamodzielnych i nietrwałych (dla każdego z nich, wśród rozmaitych statystyk, na mapie strategicznej podaje się m.in. procentową podatność rządu na korupcję!). Indywidualnego charakteru tychże gra portretować nie próbuje; wydają się i tak wyczekiwać nowego hegemona i panafrykańskiej ideologii nowego typu - przychodzącej „z zewnątrz” - zdolnej skutecznie je zjednoczyć i uwolnić od sporów, od jakich same uwolnić się nie potrafią przez swoją sugerowaną niedojrzałośćc ${ }^{40}$.

Podobną diagnozę trzeba postawić w przypadku GLA - tabuizacja islamu, której wyrazem jest świecki program terrorystów, skłoniła twórców do wyboru areny działań przyległej do Bliskiego Wschodu, tu zastąpionego poradzieckimi satrapiami Azji Środkowej. Wybór taki jest analogiczny do poczynionego przy europejskiej ekspansji Nod, gdzie sferą niestabilną także uczyniono byłe demoludy - i równie niefortunny. Vit Sisler, specjalizujący się w postkolonialnej analizie przedstawień świata arabskiego, pisząc o Generals, nie ma wątpliwości, że GLA reprezentuje Arabów ${ }^{41}$; do godła Ligi Arabskiej wydaje się nawiązywać godło terrorystów; w efekcie, podstawą programu Armii wydaje się właśnie panarabizm - należy jednak wątpić, czy zyskałby on popularność w rejonie zamieszkanym rdzennie przez ludność turkmeńską (z czego twórcy gry najpewniej nie zdawali sobie sprawy), gdzie o neokolonialny ucisk (z którym Armia ma walczyć) można oskarżyć nie Chiny i Amerykę (jak dzieje się w grze), ale najwyżej Rosję (w uniwersum w ogóle nieobecną jako mocarstwo ${ }^{42}$ ). Błędy te demaskują przekonanie autorów, że różne regiony Wschodu są zasadniczo ze sobą tożsame i niejako wymienne.

W obu przypadkach - GLA i Bractwa Nod - widać zatem, że próby znalezienia zastępnika dla Bliskiego Wschodu, postrzeganego jako matecznik terrorystów (i islamu, przez samą swą nieobecność oskarżanego pośrednio o bycie religią przemocy), prowadzą do powstawania nowych paradoksów - wskutek przyjęcia założenia, jakoby cały Orient (w $C \odot C$ rozszerzony) był bytem homogenicznym ${ }^{43}$, co miałoby legitymizować przypisywanie jego ogólnych atrybutów jego dowolnej części.

40 Zob. E.W. Said Orientalizm, s. 70.

V. Sisler Re-presentation and Self-Representation: Arabs and Muslims in Digital Games, w: Gaming realities..., s. 88. Pierwotnie w C\&C Generals dostępne miały być też Rosja i UE.

43 Jest to uproszczenie dosyć typowe dla strategii, np. w serii Tropico diagnozowane w odniesieniu do latinidad. Zob. Sh. Magnet Playing at Colonization..., s. 155. 


\subsection{Misje bliskowschodnie. Ekspansja i apokalipsa}

Opisane wyżej ramy wirtualnych wojen pokazują, że zarówno profile antagonistów Zachodu w grach $C \vartheta C$, jak i terytorialny kształt ukazywanych wojen ufundowano na płytkich paralelach historycznych i intencjonalnych alteracjach w ich obrębie, co owocuje szeregiem nieintencjonalnych paradoksów. Podobnie jest z misjami, jakie gracz musi prowadzić w toku kampanii „złych” stron - co odpowiada, w modelu Kapella, „środkowej” warstwie badanych gier (tj. celom gracza). Na mocy wspomnianej już polaryzacji etycznej wczesnych RTS-ów seria $C \odot C$ rezerwuje zadania „niegodziwe” dla kampanii „złych” stron konfliktu. Przykładem mogą być misje, które w danej kampanii gracz musi przeprowadzić jako pierwsze i ostatnie - odpowiednio, jako wprowadzające odbiorcę w specyfikę frakcji i unaoczniające mu ostateczny cel jej dążeń.

Charakterystyczny rzekomo dla wschodnich społeczeństw rys despoty$\mathrm{zmu}^{44}$ implikuje wysokie zdyscyplinowanie wschodnich armii, ale funkcjonujący równolegle stereotyp orientalnej niezdolności do samoorganizacji wymaga, aby dyscyplinę tę w fabułach naruszać - stąd też częste we „wschodnich" kampaniach zadania polegające na karaniu buntowników lub zdrajców. Jest to częsty wybór na misje początkowe - postać gracza Tiberian Sun zaczyna od włączenia się w bratobójcze walki o władzę nad Bractwem, wcześniej zaś podbój Afryki rozpoczyna w Tiberian Dawn od zabójstwa niepokornego watażki (inspiracji mógł dostarczyć realny zamach Dżihadu na egipskiego premiera ${ }^{45}$ ) i wymordowania ukrywających go wieśniaków ${ }^{46}$. Podobną misję - polegającą na chemicznym ataku na „zdradziecką” prochińską wioskę - miała zawierać kampania GLA, lecz usunięto ją z gry jako zbyt kontrowersyjną (udostępniono ją graczom dopiero w 2009 roku). Kampanię otwiera więc atak terrorystów-samobójców na chińską bazę wojskową w Szymkencie (analogiczny do głośnego zamachu na koszary MNF w Bejrucie z 1983 roku ${ }^{47}$ ). Podobny atak na placówkę GDI otwiera kampanię Bractwa w Tiberium Wars. Wszystkie te zadania mają podkreślać brak szacunku dla życia ludzkiego

\footnotetext{
44 E.W. Said Orientalizm, s. 289.

45 J.Zdanowski Historia Bliskiego Wschodu..., s. 367.

46 Zabici cywile pojawiają się ponadto w statystykach po ukończeniu każdej misji Nod (przyznawane dodatkowo punkty mają zachęcać gracza do przyjęcia "okrutnego" stylu gry w kampanii Bractwa).

47 J.Zdanowski Historia Bliskiego Wschodu..., s. 432.
} 
- własnego i cudzego - rzekomo charakterystyczny dla Orientu jako cywilizacyjnie niższego.

O ile powyższy przekaz pozostaje koherentny, z misjami finalnymi „złych" kampanii wiążą się sprzeczności wynikające z prób pogodzenia dwóch odmiennych logik, rządzących rozwojem ich fabuły - racjonalnej, związanej z ekspansywnym rysem Wschodu, i irracjonalnej, wynikającej z przymusu nadania wschodnim siłom rysu szaleńczego lub mistycznego ${ }^{48}$.Z tym ostatnim wiąże się swoisty refren, pojawiający się w fabułach $C \partial C$ - kampanie „złe” wieńczy często apokalipsa. W Tiberian Dawn jest ona wciąż „miniaturowa": podbój Afryki wieńczy uderzenie w jedną z zachodnich stolic za pomocą przejętego przez hakerów Bractwa satelity bojowego GDI, co ma pogrążyć wroga wizerunkowo. Długoterminowe cele Nod pozostają nieznane, ale Tiberian Sun dookreśla je, przydając Bractwu rys posthumanistyczny - w drugiej wojnie Kane dąży do transformacji Ziemi dzięki wielogłowicowej rakiecie balistycznej z gazem tyberiańskim, mającej zdziesiątkować populację globu (aby jej zmutowany ułamek mógł objąć go w posiadanie). Kampania GLA w Generals stawia przed graczem zadanie skromniejsze, będące kombinacją powyższych - odpalenie pocisku balistycznego z głowicą chemiczną w niesprecyzowane miasto zachodnie ${ }^{49}$. Misje te wprowadzają paradoks: cele ostateczne Nod i GLA implikują przynajmniej częściowe samozniszczenie (w Tiberium Sun gwarantowane totalnością destrukcji, w obu pozostałych przypadkach - nieuchronnością odwetu), zaprzeczając konwencjonalnej arytmetyce wojny, rządzącej daną kampanią, z wyłączeniem samego jej finału. Zasadność podboju kolejnych obszarów staje pod znakiem zapytania, gdyż kontrola nad nimi okazuje się nie mieć znaczenia w perspektywie apokalipsy, która musi je unicestwić, ktokolwiek by nimi władał. Finał taki przeczy więc celowości uprzednich wysiłków gracza.

Identyczne paradoksy wiążą się z fabułami rozszerzeń do opisanych gier, osnutymi najczęściej wokół powojennego buntu w szeregach wschodnich armii: intryga Zero Hour ${ }^{50}$ ogniskuje się na walkach o przywództwo w łonie

48 E.W. Said Orientalizm, s. 89.

49 Finalne misje Wschodu podkreślają jego zacofanie także wymaganiem, aby to postać gracza w misjach poprzedzających wykradła narzędzie zagłady (odpowiednio: kody do satelity GDI, artefakt kosmitów z wiedzą niezbędną do konstrukcji tyberiańskiej rakiety, wreszcie: poradziecki pocisk).

EA Games, Command \& Conquer: Generals. Zero Hour, Electronic Arts 2003. 
pokonanej GLA, zaś Firestorm ${ }^{51}$ i Kane's Wrath ${ }^{52}$ opowiadają o rebeliach dwóch sukcesywnych superkomputerów Nod (CABAL-a i LEGION-a) po drugiej i trzeciej wojnie z GDI. W obu przypadkach początkowa rywalizacja militarna z siłami danej rebelii także ustępuje szybko miejsca przeciwdziałaniu apokalipsie (w tym przypadku: buntowi maszyn rodem z Terminatora, ale z podtekstem religijnym). Fabuła obu serii - tyberiańskiej i Generals - próbuje zatem łączyć ekspansywny rys Orientu z przypisywaną mu irracjonalnością, przez co traci spójność, ilekroć zbliża się do finału, nie mogąc wybrać między dwoma nieuzgadnialnymi charakterystykami Wschodu ${ }^{53}$.

\subsection{Arsenały bliskowschodnie. Ubóstwo, złodziejstwo i dżin w butelce}

We wszystkich grach spod znaku $C \partial C$ kształtem danego arsenału rządzi podwójna dialektyka: siły i słabości z jednej strony oraz otwartej walki i podstępu z drugiej. Terrorystom (Nod i GLA) oddano wachlarz jednostek sprofilowany pod tymi dwoma względami w identyczny sposób: Wschód wydaje się technicznie słabszy. Widać to już w samej strukturze baz, jakie Chińczycy i Amerykanie w Generals wznoszą za pomocą buldożerów, stosując do transportu niezbędnych surowców ciężarówki i helikoptery - kiedy w GLA oba te zadania wykonują piesi robotnicy (pracujący szybciej, gdy dokupić im buty ${ }^{54}$ ), Podobnie zróżnicowano sposób produkcji jednostek w Generals i Tiberian Dawn. Zachodnie armie wytwarzają sprzęt bojowy na miejscu ${ }^{55}$, terroryści w obu grach jedynie go kupują - odpowiedniki fabryk stanowią w ich bazach, odpowiednio, lądowiska dla transportowców i targowiska (dowcipnie nazwane „czarnym rynkiem”), co implikuje brak technicznej samowystarczalności Wschodu.

Westwood Studios, Command \& Conquer: Tiberian Sun. Firestorm, Electronic Arts 2000.

EA Los Angeles, Command \& Conquer 3: Kane's Wrath, Electronic Arts 2008.

Fabuły C\&C uzasadniają wcześniejszą ekspansję danej frakcji dążeniem do apokaliptycznego aktu finalnego, ale to w sposób nieprzekonywający (zajęcie Afryki - budową elektronicznej twierdzy dla hakerów Nod; podbój Azji Środkowej przez GLA - chęcią zajęcia kosmodromu w Bajkonurze). Cele wojny, jakie wyliczono, nie wymagają wejścia w pełnowymiarowy konflikt, przynależąc do odrębnego porządku: terroru, nie wojny.

54 charakteru, rolę centrów dowodzenia odgrywają tam pałace o złotych kopułach (jeden z liderów Armii nosi tytuł księcia).

W ramach rozpowszechnionego w RTS-ach uproszczenia. 
Zapóźnienie cywilizacyjne terrorystów widać też, gdy porównać armie Nod i GLA z wojskami ich adwersarzy. Siły Orientu pozbawione są całych kategorii sprzętu bojowego. Zachód może oprzeć się na ultranowoczesnym lotnictwie (co realnie stało się standardem od czasu wojny w Zatoce Perskiej $\left.{ }^{56}\right)$. U terrorystów składa się ono z garści poradzieckich maszyn: grając po stronie GLA, gracz może wskazywać cele pojedynczym bombowcom Tu-4 $\mathrm{z}$ bombami biologicznymi, ale sam nie może wytwarzać żadnych statków powietrznych (Armia nie posiada lotnisk). Podobnie jest z lotnictwem Nod w Tiberian Dawn (tylko transportowe An-22 i niedostępne w kampanii śmigłowce Mi-24 $\left.{ }^{57}\right)$. Wschód musi więc walczyć wojskami lądowymi - ale i te są zdecydowanie słabsze od zachodnich. Uwypukla to już ich stylizacja i nomenklatura: standardowej piechoty Nod nie stanowi w Tiberium Wars wojsko, lecz ochotnicza milicja w cywilnych ubraniach, podobnie z piechotą GLA. Gracz może werbować grupy demonstrantów („wściekły tłum”) i rozdać im karabiny, zaś bojówkom Nod przydać profesjonalnych „spowiedników” - ulepszenia te podkreślają jednak amatorski charakter obu formacji, odsyłając do wschodniej niezdolności do samoorganizacji. Mimo to gracz jest zachęcany do wykorzystania piechoty ${ }^{58}$.

Słabość wojsk Orientu dotyczy także pojazdów. Wybierając GDI lub USA w opisywanych grach, gracz do rozpoznania terenu może używać nowoczesnych pojazdów Humvee - grając po stronie Nod lub GLA, skazany jest na broń prowizoryczną: motocykle z wyrzutniami rakiet czy półciężarówki z karabinami maszynowymi (ikoniczne dla wojen w Trzecim Świecie ${ }^{59}$ ). Broń pancerna terrorystów jest często nie tyle słabsza od zachodniej, co pochodzi z zachodniego demobilu: w Tiberian Dawn po stronie Nod gracz używa amerykańskich transporterów opancerzonych jako lekkich czołgów (M2 Bradley), zaś po stronie GLA w Generals - fikcyjnych wersji włoskiej tankietki z II wojny światowej (P-40; w grze jako Scorpion). W obu grach Zachód przeciwstawia im współczesne, ikoniczne dla wojny w Zatoce Perskiej czołgi M1 Abrams

56 Zob. W.J. Boyne Skrzydła wojny, s. 414.

Np. poprzez unikalną dla terrorystów możliwość przekształcenia transporterów w prowizoryczne bunkry w Tiberium Wars (fikcyjne pojazdy Reckoner) i Zero Hour (opancerzone autobusy miejskie).

59 Konflikt graniczny między Czadem i Libią w 1987 roku nazwano "wojną toyot”. Zob. B. Davidson Społeczna i polityczna historia Afryki..., s. 120. 
(w Generals jako fikcyjne Crusader), nie wspominając już o czysto fantastycznych superczołgach (fikcyjne wehikuły Mammoth i Paladin).

Dla zbalansowania gry przewagę Zachodu w broni konwencjonalnej siłom wschodnim należało zrekompensować - i to na kilku płaszczyznach. W defensywie silniejsze systemy obronne pomagają skutecznie odpierać szturm zachodnich czołgów; nękać je atakami z zaskoczenia pozwala monopol na niewidzialne jednostki; wreszcie: lepsza artyleria i efektywniejsza superbroń niwelują słabość sił konwencjonalnych w czasie szturmu na bazę wroga. Przyznanie Wschodowi - w zakresie tych czterech typów broni - wynalazków lepszych od zachodnich bez dodatkowych zastrzeżeń zaprzeczałoby jednak dogmatowi o technicznym zacofaniu. Źródłem owych technologii czyni się zatem nieodmiennie siłę wobec Wschodu zewnętrzną: albo sam Zachód, albo istoty pozaziemskie, odsyłając gracza - odpowiednio - bądź do rysu imitacyjnego Orientu ${ }^{60}$, bądź też do orientalnej cudowności. O ile więc GLA kamufluje jeszcze piechotę i budynki z użyciem zwyczajnych siatek maskujących, niewidzialne czołgi Nod wykorzystują już „nieziemską” technikę (w Tiberian Sun jej źródłem okazują się kosmici), co uwypukla „mistyczna” jej nomenklatura (np. urządzenie maskujące instrukcja nazywa „tarczą Łazarza"61). Mistycyzuje się też artylerię i systemy obronne Nod, bazujące na broni laserowej - wieże strażnicze tego rodzaju nazywa się „Obeliskami Światła”, co niejako przepisuje je z porządku technicznego w magiczny.

W przypadku GLA przewaga terrorystów na czterech wyliczonych polach jest tłumaczona inaczej: użyciem wynalazków zagranicznych, których Zachód wyrzekł się z powodów etycznych - baz GLA wprawdzie bronią posterunki z konwencjonalnymi pociskami Stinger, lecz rolę artylerii i superbroni pełnią u terrorystów posowieckie pociski Scud z gazem bojowym (kojarzone w USA z wojną w Zatoce, podczas której amerykańskie lotnictwo „polowało” na irackie wyrzutnie identyczne z tymi w grze, używane przeciw izraelskim miastom ${ }^{62}$ ). To samo dotyczy pominiętej we wcześniejszym wyliczeniu superbroni Nod, czyli pocisków jądrowych, których Bractwo nie wynajduje, ale kradnie ${ }^{63}$. Dzięki tym zabiegom źródła zagrożenia, jakie stanowi w obu

60 Zob. E.W. Said Orientalizm, s. 103.

61 Kane w jednej z odpraw określa ten sam projekt mianem "koła Ezechiela”, co stanowi popularne w popkulturze biblijne odniesienie do UFO. L. Znicz Paleoastronautyka, Krajowa Agencja Wydawnicza, Gdańsk 1980, s. 214-217.

62 J.Zdanowski Historia Bliskiego Wschodu..., s. 483.

63 Kradzieży dokonuje gracz, i to dwukrotnie (bliźniacze misje w Tiberian Dawn i Tiberium Wars). 
cyklach Wschód, zostają określone jako zewnętrzne w stosunku do niego samego - co pozwala ocalić wizerunek Orientu jako niezdolnego do samodzielnego osiągnięcia przewagi technicznej.

\section{Mocarstwa dalekowschodnie w $\boldsymbol{C} \&$ C. Alternatywna Rosja, Japonia i Chiny} Nieomówiona dotąd trzecia podseria $C \odot C$ - trylogia Red Alert - zastępuje „nowoczesne" ramy wojny z terroryzmem klasycznymi kliszami zimnowojennymi. Punkt dywergencji umieszczony jest pół wieku wcześniej - jest nim podróż w czasie, podjęta po II wojnie światowej przez rozgoryczonego Alberta Einsteina, który wymazuje z przeszłości Republiki Weimarskiej młodego Adolfa Hitlera. W rezultacie II wojna światowa (i dwie następne) rozgrywa się - w zastępstwie zimnej wojny - między blokiem zachodnim i Związkiem Sowieckim, pozbawionym w alternatywnej Europie przeciwwagi, jaką (jakoby) stanowiłaby dlań realnie III Rzesza. Sama idea sugeruje, że realny ZSRR nie był równorzędnym wrogiem dla Zachodu - skoro zimną wojnę przegrał, w istocie był od niego słabszy; Sowietom przypisują więc twórcy gry wrodzoną Wschodowi nieudolność, której historia musiałaby dopiero wyjść naprzeciw, aby Stalin mógł podbić Europę w latach 40. (gdy toczy się Red Alert). Twórcy przeczą w ten sposób przebiegowi realnej wasalizacji Europy Wschodniej przez Stalina, w której - wedle niektórych historyków - III Rzesza odegrała rolę katalizatora ${ }^{64}$.

Seria mistycyzuje nawet sam komunizm, który instrukcja do Red Alert opisuje, jakby był azjatycką religią - jej dogmaty jakoby miały się objawić Stalinowi w snach (sic!), zaś wszelkie sukcesy tyrana-mistyka wydają się owocem manipulacji jego bardziej pragmatycznego zausznika ${ }^{65}$. Sugestię, jakoby Azja do walki z Zachodem potrzebowała lidera "z zewnątrz", powtarza Red Alert ${ }^{66}$, stawiając przy boku nieudolnego premiera - wzorowanego na Chruszczowie impulsywnego Aleksieja Romanowa - makiawelicznego telepatę Jurija, inspirowanego Rasputinem. Rosja w $C \partial C$ nie jest więc mocarstwem, ale imitacją mocarstwa - źródła jej potęgi są zasadniczo zewnętrzne.

\footnotetext{
64 Tzw. interpretacja realistyczna przedwojennej dyplomacji sowieckiej, wyznawana przez część historyków. Zob. M. McCauley Narodziny i upadek Zwiq̨zku Sowieckiego, przeł. Z. Landowski, Książka i Wiedza, Warszawa 2010, s. 260.

65 W finale kampanii okazuje się nim Kane z Bractwa Nod (tu będącego analogiem Iluminatów). Więź z serią tyberiańską znika w Red Alert 2.

66 Westwood Pacific, Command \& Conquer: Red Alert 2, Electronic Arts 2000.
} 
Nieudolność sowieckich liderów eksponuje też Red Alert $3^{67}$, gdzie podjęta przez nich podróż w czasie osłabia USA, lecz za cenę przydania obu krajom wroga jeszcze gorszego - stechnicyzowanej Japonii. Zagrożenie, jakie stanowi ta ostatnia, jest „sztuczne”, jak to sowieckie w pierwszej części gry - wymaga usunięcia podczas konferencji Solvaya w 1927 roku Alberta Einsteina, odpowiedzialnego za zachodnią przewagę techniczną podczas obu wojen. Przemilczany związek tej zmiany z ekspansją Tokio sprowadza się do sugestii, jakoby tylko „nienaturalne” osłabienie Stanów Zjednoczonych uniemożliwiło im pokonanie Japończyków w alternatywnej II wojnie światowej ${ }^{68}$. Fabuła gry zasadza się więc za supozycji, jakoby Azja mogła zwyciężyć Zachód tylko wtedy, gdy Zachód nie zdoła jej „upilnować” - wbrew temu, że realnie właśnie porażka Japonii i jej powojenna transformacja legły u podstaw późniejszego cudu gospodarczego (do lat 70. owocując pozycją lidera przemysłu elektronicznego ${ }^{69}$, do czego nawiązuje futurystyczna technika Cesarstwa w Red Alertz!). Sowiecka wyprawa w przeszłość - jak wcześniej ta, podjęta przez samego Einsteina - powinna więc przynieść skutek odwrotny od przedstawionego.

Podobna logika stoi za alternatywną formułą polityczną Chin Ludowych w Generals, które - w ramach ocieplania wizerunku - równorzędną pozycję wobec Waszyngtonu w wojnie z terroryzmem wydają się zawdzięczać liberalizacji polityki wewnętrznej, czyli przyjęciu zachodnich wzorców. Nie przeszkodziło to jednak twórcom w warstwie rozgrywki umieścić odniesień do realnej ChRL (gracz np. może stawiać szczekaczki w chińskich bazach, pozwalające leczyć pobliską piechotę), odsyłając do azjatyckiego despotyzmu i podstępności. W przypadku trzech mocarstw - ZSRR, Japonii i Chin - seria stosuje więc podobne uogólnienia, jakie siostrzane serie stosowały w odniesieniu do Nod i GLA, co rodzi bardzo podobne sprzeczności, także i tu warte omówienia oddzielnie na trzech płaszczyznach.

\subsection{Kampanie dalekowschodnie. Migotliwe granice imperiów}

Analizę teatrów działań mocarstw Wschodu w C $\partial$ C trzeba zacząć od konstatacji, że geografia Europy Wschodniej i Azji wydaje się sprawiać twórcom

67 EA Los Angeles, Command \& Conquer: Red Alert 3, Electronic Arts 2008.

O uczestnictwie w niej Japonii świadczy obecność prozachodniej Korei wśród aliantów USA w Red Alert 2. 
nie mniej kłopotów niż Bliski Wschód. Chęć jednoczesnego przywołania klisz zimnowojennych i ich uniknięcia sprawia, że już w Red Alert w początkach fikcyjnej II wojny światowej granicą sowieckich dominiów uczyniono Łabę - usunięcie Hitlera nie tłumaczy jednak, w jaki sposób Rosjanie zajęli Europę Wschodnią! Przedwojenne dominia Stalina jeszcze inaczej ukazuje Red Alert 2 - na jednej z plansz, które podczas instalacji gry mają wprowadzać nowych odbiorców w fabułę części pierwszej, widać mapę zupełnie odmienną od oryginalnej, z której wynika, że ZSRR u progu inwazji kontrolował nie tylko obszar realnego Układu Warszawskiego, ale i realne terytoria Osi ${ }^{\mathbf{7 0}}$ (Włochy i całość Niemiec). Skromniejsze błędy tego typu widać już na mapie strategicznej pomiędzy misjami w Red Alert, gdzie międzywojenne granice wprawdzie biegną poprawnie, ale chęć ich uproszczenia skłoniła grafików do drobnych „korekt”, w których rezultacie wymazano zeń nie tylko Luksemburg, ale i republiki bałtyckie czy Prusy Wschodnie. Tego rodzaju zabiegów wybronić oczywiście nie sposób - świadczą one o braku zainteresowania twórców gry arkanami zamorskiej geografii, z ich punktu widzenia: w oczywisty sposób nieistotnymi dla przeciętnego odbiorcy amerykańskiego.

Innego typu kontrowersje dotyczą składu bloku wschodniego w Red Alert 2. Jako obieralne frakcje bloku sowieckiego, w grze wieloosobowej - w miejsce realnych republik związkowych ZSRS, jak było w Red Alert - pojawiają się, oprócz Rosji i Kuby, także Libia i Irak. O ile obecność pierwszej pary jest zrozumiała, obecność drugiej budzi wątpliwości. Realne reżimy Husajna i Kaddafiego istotnie korzystały bowiem z pomocy Moskwy, ale w latach 70. - w kolejnej dekadzie, stosunki te się załamały (w efekcie, odpowiednio, „nieautoryzowanej" wojny z Czadem $^{71}$ i konfliktu irańsko-irackiego ${ }^{72}$ ) i wydaje się, że sportretowanie obu reżimów (wciąż istniejących w chwili wydania gry) jako sowieckich satelitów wynikało raczej z ich antyzachodniego statusu, niż realnych politycznych afiliacji. Trzej sojusznicy alternatywnej Rosji pojawili się też wśród sześciu głównych wrogów realnej Ameryki, jakich w dwa lata po premierze Red Alert 2 - administracja Busha zaliczyła do „osi zła"73; gra stawia zatem znak równości pomiędzy komunizmem i wszelkimi

Mapa ta uwzględnia też nie tylko powojenne przesunięcia granic, ale i republiki poradzieckie.

J. Zdanowski Historia Bliskiego Wschodu..., s. 486.

B. Davidson Społeczna i polityczna historia Afryki..., s. 120.

Trzy wyliczone kraje padają na tej liście, oprócz Iranu i Korei Północnej (wraz z Irakiem tworzących "oś zła") i Syrii (z Libią i Kubą dodanej do tej trójki przez podsekretarza stanu Johna Boltona). J. Zdanowski Historia Bliskiego Wschodu..., s. 493. 
antyamerykańskimi ideologiami Trzeciego Świata, ignorując wszelkie różnice jako nieistotne.

Jeszcze inne przeinaczenia można napotkać w Generals i Red Alert 3 w odniesieniu do dwóch mocarstw Azji Wschodniej: ChRL i Japonii. O ile teatr wojny z GLA ograniczono do Azji Środkowej, ChALW w dodatku Zero Hour ściga terrorystów aż do Niemiec (sic!), operując tam bez sprzeciwu ze strony lokalnych mocarstw - w tym: Rosji, przez którą Chińczycy realnie musieliby przejść! Układ sił w uniwersum jest dwubiegunowy - obejmuje tylko Pekin i Waszyngton - co wydaje się podyktowane przede wszystkim chęcią przeniesienia roli ofiary terrorystów z Ameryki (choć to ona wymierza im karę) na państwo trzecie. Japońska ekspansja w Red Alert 3 wiąże się z błędem do tamtego symetrycznym - tym razem to Chiny zostają pominięte na rzecz Rosji, gdy Japonia napada na ZSRR w początkowej fazie kampanii, aby uniknąć odtwarzania Pearl Harbor - jakby dla podkreślenia, że w grze Cesarstwo nie jest siłą jednoznacznie „złą”, gdyż akurat Amerykę traktuje honorowo (w grze cesarz wypowiada bowiem wojnę USA przed zajęciem Kalifornii). W obu przypadkach widać rażącą ogólnikowość w podejściu do geografii Azji Wschodniej - twórców nie interesuje realny region w swym realnym kształcie, lecz tylko tożsamość lokalnego hegemona.

\subsection{Misje dalekowschodnie. Inwazje i kataklizmy}

W przypadku mocarstw Orientu sprofilowanie misji ma charakter podobny, jak w przypadku misji terrorystów - i tu wystarczy przyjrzeć się zadaniom otwierającym i wieńczącym daną kampanię. Sowiecki podbój Europy w Red Alert rozpoczyna gracz od pacyfikacji przedmieść Torunia, aby ukarać Polaków za wsparcie udzielone prozachodnim partyzantom, a w Red Alert 2 - od inwazji na Wschodnie Wybrzeże (nawiązanie do Red Dawn Johna Miliusa). Wizję „orientalnej” brutalności złagodzono nieco wobec Japonii i Chin z powodów marketingowych - toteż, w pierwszym przypadku, „rosyjska” wersja Pearl Harbor (atak na Workutę) obejmuje tylko przemoc symboliczną wobec ludności cywilnej (gracz burzy lokalne pomniki, aby złamać morale wroga; powtórzyć tę czynność musi później wobec słynnych figur Stalingradu). W drugim przypadku unik jest innego rodzaju: do masakry dochodzi, lecz zmienia się jej sprawca - w pierwszej misji Chińczyków to GLA detonuje taktyczny ładunek jądrowy podczas defilady na placu Tiananmen. Zadaniem gracza jest ukarać winnych, ale później sam musi wykazać się równie ciężką ręką - w ferworze walki, burząc centrum kongresowe w Hongkongu czy 
Tamę Trzech Przełomów (co władze ChRL uznały za dostatecznie gorszące, by zakazać sprzedaży gry $\left.{ }^{74}\right)$.

Finałowe partie odpowiednich kampanii w części i tu noszą ten sam rys apokaliptyczny, co analogiczne zadania Nod czy GLA - co owocuje podobnymi paradoksami. Wyjątkowość scenariusza apokaliptycznego w Red Alert polega na tym, że ten pojawia się wyłącznie w kampanii Aliantów. Wątek szaleństwa Stalina, który pragnie zniszczyć świat z pomocą broni jądrowej" w kampanii sowieckiej w ogóle nie istnieje - tam wojna jest konwencjonalna, zaś Stalin nie jest szalony, inaczej bowiem wysiłki gracza nie miałyby sensu. W Red Alert 3 podobny paradoks wiąże się z „boskim przeznaczeniem” prowadzącym cesarza Yoshiro ku kolejnym podbojom. Gdy okazuje się, że nic takiego nie istnieje, zaś potęga Cesarstwa jest owocem temporalnej pomyłki, cesarz załamuje się - wojna okazuje się więc efektem nieporozumienia (co przypomina oficjalną linię obrony Hirohito, jaką po wojnie lansował MacArthur). Inwazję na Amerykę i tak kontynuuje jednak książę Tatsu - już bez mandatu niebios, czyli niejako wbrew logice całego odkrycia (co więcej: ojciec ostatecznie przyłącza się do niego!). Także i zreferowane tu fabuły obnażają skłonność twórców serii do portretowania Wschodu jako irracjonalnego, co wchodzi w tak jaskrawą sprzeczność z prostą logiką podboju, że spoistość opowieści trzeba ratować rozmaitymi trikami.

Jak w przypadku serii tyberiańskiej, także w Red Alert to temat apokaliptyczny funduje fabuły rozszerzen - wraz z tematem buntu, pozwalającym wprowadzić do gry wroga wspólnego dla obu zwaśnionych stron. W Yuri's Revenge ${ }^{76}$ jest nim wspominany telepata Jurij, który w finale kampanii Red Alert 2 przejmuje władzę na Kremlu, manipulując chorym premierem (co odsyła do triumwiratu Andropowa, Gromyki i Ustinowa w późnej epoce Breżniewa). Choć kampania kończy się pokonaniem telepaty, ten powraca w rozszerzeniu, pragnąc mentalnie zniewolić już całą planetę (zaś gracz musi go powstrzymać). Rozszerzenie Uprising ${ }^{77}$ do Red Alert 3 fundują te same dwa tematy - kataklizmu i rebelii - lecz zostają one rozdzielone: pierwszy realizuje się w temporalnym holokauście, jaki szykuje komunistom paneuropejska korporacja

D. Becker Banned in Beijing: China cracks down on games, CNET, online: http://www.cnet.com/ news/banned-in-beijing-china-cracks-down-on-games/ (23.12.2015).

Gracz kieruje szturmem na sowiecki ośrodek atomowy o wymownej nazwie Temnyj Wsadnik, aby zapobiec odpaleniu rakiet balistycznych w kierunku Paryża i Londynu.

Westwood Pacific, Command \& Conquer: Red Alert 2 - Yuri's Revenge, EA Games 2000. 
FutureTech, drugi - w tytułowym powstaniu podbitej Japonii przeciw USA. Fabuła czerpie inspirację nie tylko z ery MacArthura (Tatsu po koronacji współpracuje z Waszyngtonem niczym Hirohito), ale i z epoki restauracji Meiji - gdyż bunt przeciw prozachodniej polityce tronu wszczynają konserwatywni szoguni, co odsyła do historycznej rebelii w Satsumie (czy raczej do Ostatniego samuraja). Paradoks polega na tym, że w realnej Japonii powszechna duma z tempa modernizacji na wzór zachodni stała się równie istotnym czynnikiem dla wzrostu nastrojów nacjonalistycznych, co tradycjonalizm ${ }^{\mathbf{7 8}}$. Japonia, gdzie samuraje istnieliby nadal, nie mogłaby zostać nowoczesnym mocarstwem, czego twórcy Red Alert 3 albo nie byli świadomi, albo przyznali priorytet „dodatkowej” orientalizacji Japonii poprzez jej celową archaizację.

\subsection{Arsenały dalekowschodnie. Ludzka fala i atom}

W zakresie konstrukcji arsenałów mocarstwa wschodnie skontrastowano z zachodnimi według podobnej dialektyki, jak wcześniej siły terrorystów: siły i słabości, skrytości i jawności, zaawansowania i zacofania - cechy te inaczej jednak połączono i rozdystrybuowano. Terroryści w $C \odot C$ są jednocześnie słabsi w otwartej walce, podstępni i zacofani (nie licząc technologii obcego pochodzenia). Mocarstwa Wschodu są zacofane, ale i silniejsze zarazem niezdolne za to do skrytości przez techniczny prymitywizm (logika ta wiąże zaawansowaną technikę z podstępem, który przestaje być „niehonorowy” i staje się ekskluzywnym orężem Zachodu). Archaizację tę widać już w sferze graficznej: od Red Alert 2 normą stała się folkloryzacja wschodnich baz, dotycząca też Japonii w Red Alert 3 i Chin w Generals ${ }^{79}$.

Wśród jednostek, ta charakterystyka - opozycja siły i finezji - widoczna jest głównie w broni pancernej trzech mocarstw. W przypadku lotnictwa i marynarki: dotyczy tylko Chin i Japonii, których arsenały tworzono bardziej świadomie (w serii Red Alert rodzaje jednostek sowieckich obu tych typów ewoluują). Japońska marynarka jest równie silna co flota USA, ale mniej finezyjna (brakuje np. lotniskowców). Lotnictwo szturmowe ChALW w Generals

78 T.W. Hall Historia Japonii, s. 242.

W RA2 część sowieckich gmachów wieńczą kopuły cerkiewne, mające kojarzyć się z Placem Czerwonym, w niektóre japońskie budynki w RA3 "wbudowano" bramy torii, zaś w budynki ChALW w Generals - podłużne pawilony o wygiętych dachach i koliste, tarasowe wieże, przypominające pekińskie zabytki (odpowiednio: Bramę Niebiańskiego Spokoju i Świątynię Nieba), co i tak stanowi złagodzone wersje projektów. Zob. h.Robb szkice do C\&C Generals, https:// cncguild.net/oldindex.php?page=gen/conart/bld (12.10.2015). 
przypomina z kolei „toporną” wersję amerykańskiego (gra ultranowoczesnym F-16 i niewidzialnym F-117 przeciwstawia pozornie starsze odeń MiG-i ${ }^{\mathbf{8 0}}$ ), podobnie bombowce (B-52 odpowiadają sędziwe Tu-16 w chińskiej wersji Xian H-6 ${ }^{81}$ ). Te same maszyny (tj. Tu-16 i starsze MiG-i) w Red Alert pojawiają się w sowieckim arsenale - tam jednak dają ZSRR przewagę (możliwe odwołanie do mitu luki bombowcowej ${ }^{\mathbf{8 2}}$ ). Znamienne, że w sequelu przewaga ta znika - lotnictwo ZSRR przechodzi inwolucję, zredukowane do groteskowych sterowców; za to w odwrotnym kierunku rozwija się w serii Czerwona Flota (pierwotnie zawężona do okrętów podwodnych, zgodnie z realną doktryną Gorszkowa), zrównana z U.S. Navy dzięki addycji osłony przeciwlotniczej i krążowników rakietowych (funkcjonalnie będących w grze „prymitywnym" ekwiwalentem amerykańskich lotniskowców). Ewolucja ta zmierza do przeciwstawienia orientalnej brutalności zachodniej finezji.

Odmienną politykę przyjęto wobec piechoty azjatyckich wojsk, która jak ta terrorystów - jest od zachodniej nieodmiennie słabsza. Niższość tę podkreśla już wygląd i nomenklatura odpowiednich formacji: trzon ChALW tworzą młodzieńcy w mundurach z lat 6o., zwani Czerwoną Gwardią (niefortunna referencja do bojówek studenckich z czasów rewolucji kulturalnej3 oraz jedna z przyczyn zakazu sprzedaży gry w Chinach), w Armii Czerwonej służą „poborowi”, w wojsku cesarskim zaś - „wojownicy” w quasi-samurajskich zbrojach i hełmach z shikoro. Anachroniczność tych formacji zostaje podkreślona także przez prymitywizm alternatywnego uzbrojenia: możliwość walki mieczami samurajskimi przez Japończyków, bagnetami przez Chińczyków ${ }^{84}$ czy wyekwipowanie sowieckich sołdatów w RedAlert 3 w koktajle Mołotowa ${ }^{85}$. Jak w armiach terrorystów, zbalansowanie starć piechoty osiąga się, sprawiając, aby gracz produkował jej po prostu więcej, niż gdyby

80 Paradoksalnie: graficznie wzorowane na realnych MiG-1.44 piątej generacji, czyli znacznie lepszych.

81 Zob. B. Potyrała, R. Fudali Od zwycięstwa do upadku. Siły zbrojne Zwiq̨zku Radzieckiego 1945-1991, Wydawnictwo Naukowe PWN, Warszawa 2009, s. 424.

82 Zob. E. Schlosser Poza kontrolq̨. Broń jądrowa i iluzja bezpieczeństwa, przeł. K. Bażyńska-Chojnacka, Wydawnictwo Naukowe PWN, Warszawa 2015, s. 195.

83 Zob. P. Johnson Historia świata XX wieku, t. 2.: Od Rewolucji Październikowej do Solidarności, przeł. A. Szostkiewicz, Fijorr Publishing, Warszawa 2009, s. 322-325.

84 Ulepszenie to ostatecznie wycięto z gry.

85 Biorąc pod uwagę realną genezę terminu - jest to referencja równie niefortunna, co ta do hunwejbinów. 
grał armią zachodnią - zachęcać go do tego mają premie: „darmowi” rekruci (otrzymywani przy werbunku ${ }^{86}$ lub dzięki zrzutom spadochronowym ${ }^{87}$ ), chiński i radziecki monopol na konstrukcję bunkrów, czy tzw. bonus hordy, zwiększający siłę ognia piechoty ChALW w dużych grupach ${ }^{88}$. Zachęca to gracza do stosowania taktyki ludzkiej fali - w USA kojarzonej z ChRL po wojnie koreańskiej ${ }^{89}$ (podczas której powszechnie postrzegano ChOL jako „fanatyczne hordy" $\left.{ }^{\prime \prime 0}\right)$. Odpowiada to nie tylko wyobrażeniu Orientu jako nieliczącego się z życiem jednostek, ale i - jako niewyczerpanego rezerwuaru zasobów ludzkich (lub po prostu: roju ${ }^{91}$ ).

Piechota stanowi wyjątek od reguły, przyznającej armiom Wschodu wojska silniejsze w walce bezpośredniej. W arsenałach terrorystów rekompensatą za słabość na tym ostatnim polu była obecność lepszych jednostek obronnych i wsparcia (artylerii i superbroni). Choć wojska mocarstw Wschodu w $C \partial C$ są owej słabości pozbawione, tę ostatnią przewagę zachowują - i wyższość odpowiednich typów broni nad ich ekwiwalentami zachodnimi musi zostać „wytłumaczona”, aby nie kolidowała z „naturalną" słabością Orientu. Gry odwołują się i tu do dwóch klasycznych rysów tego ostatniego - imitacyjności i mistycyzmu. Pierwsze rozwiązanie wybrano dla sowieckich wież strażniczych, porażających wrogów piorunami - nazywając je cewkami Tesli (co sugeruje, że słynny wynalazca alternatywną II wojnę światową spędził w Moskwie, zamiast w Nowym Jorku - czyniąc Stalinowi „niezasłużony” prezent ze swych prac). ChALW i armia Jurija zamiast tego korzystają z działek systemu Gatlinga (sama nomenklatura podkreśla już zachodnie pochodzenie broni, sugerując transfer technologii), wreszcie Japonia stosuje broń promienistą podobną do broni „pryzmatycznej” USA (wprowadzonej w Red Alert 2, co i tutaj sugeruje „kradzież”). Tą samą broń stosuje artyleria japońska, sowiecka

86 Czerwonogwardziści w Generals szkolą się parami; w RA2 podobny efekt dają ZSRR zbiorniki klonujące.

87 Nawiązanie do mitu o sile wojsk powietrzno-desantowych ZSRR. Zob. B. Potyrała, R. Fudali Od zwycięstwa do upadku..., s. 424.

Bonus ten dotyczy też czołgów, posiada też swój odpowiednik w lotnictwie szturmowym i artylerii ChALW (używających napalmu) - w postaci efektu burzy ogniowej, możliwej do wywołania tylko poprzez zmasowany ostrzał, co zachęca do atakowania w dużych grupach.

89 M. Hastings Wojna koreańska, przeł. B. Cendrowska, Wydawnictwo Dolnośląskie, Wrocław 2010, s. 165 .

Tamże, s. 163.

91 E.W. Said Orientalizm, s. 107. 
zaś - rakiety V-2 ${ }^{\mathbf{9 2}}$ (później V-3 i V-4; zatem sugeruje się, że nie powstałyby one, gdyby Stalin nie „przechwycił” prac von Brauna, choć ten „należał się” Amerykanom!), chińska natomiast - działa jądrowe (pozornie rodzime, ale ikona produkcyjna odsyła do znanej fotografii z atomowej próby Upshot-Knothole, przypominając o pierwszeństwie USA na tym polu).

Superbroń Wschodu także tłumaczy swoją siłę obcym pochodzeniem o ile w przypadku Japonii i wojsk Jurija opiera się ona na mocach parapsychicznych (realizując mistyczny rys Orientu), o tyle ChRL i ZSRR stosują tu - jak Nod - broń nuklearną, której wtórność w pierwszym przypadku sygnalizuje się tylko estetycznie (chińskie rakiety wzorowano nie na realnych pociskach balistycznych z rodziny Dongfeng, ale na pionierskich, amerykańskich Atlasach, startujących z charakterystycznych „trumien”). W drugim przypadku, wyeksponowano ją równie mocno na płaszczyźnie fabularnej: w RedAlert bomba atomowa to wynalazek sowiecki - aby podkreślić, że tylko dzięki zmianie historii została ona „ukradziona” Ameryce ${ }^{93}$ ! W Red Alert 3 idea ta prowadzi wręcz do paradoksu, bowiem usunięcie Alberta Einsteina - uważanego za duchowego ojca projektu Manhattan z powodu słynnego listu do Roosevelta - powoduje nagłe wymazanie pocisków jądrowych z s o w i e c ki e g o arsenału ${ }^{94}$. Orient jest więc silniejszy od Zachodu nie swoją własną siłą, ale siłą skradzioną - dzięki czemu może przerażać, zarazem jednak zostaje ocalony dogmat o jego immanentnym zacofaniu.

\section{Podsumowanie}

Jak starałem się pokazać, wizje Wschodu w grach Command $\Theta$ Conquer ucieleśniają wiele klasycznych stereotypów na temat Orientu, o jakich pisał jeszcze Said; historia alternatywna jako gatunek stwarza jedynie dodatkowe pole dla manipulacji. O ile odwzorowanie tego, co dotykalne - np. modeli sprzętu wojskowego - może pozostać wierne, wschodnia mentalność nie podlega w cyklu nawet częściowej replikacji, zastąpiona przez niespójny konglomerat klisz historycznych (z różnych okresów) i powiązanych z nimi stereotypów. Wschód w $C \odot C$ jest zawsze ekspansywny, choć zarazem nieudolny; chytry, rzeczywistego mitu luki rakietowej. Zob. E. Schlosser Poza kontrolą..., s. 226.

94 O miejscu narodzin realnej atomistyki przypomina się graczowi także później, kiedy w jednej z misji sowieckich musi przechwycić amerykański ośrodek jądrowy. 
ale irracjonalny; silny, lecz niezdolny do efektywnego wykorzystania swojej siły. Atrybuty te przeniesiono na fikcyjnych liderów pięciu opisanych sił (niezdolnych do odnoszenia zwycięstw bez pomocy doradców o zachodniej umysłowości), których cele przekładają się na zadania strategiczne (kampanii) i taktyczne (misji), jakie gracz musi realizować pod sztandarami Orientu w opisywanych grach. Cechy te także przekładają się na profile wschodnich armii, co zmusza gracza do używania wyłącznie tych taktyk, jakie uznano za odpowiednio „wschodnie” (czyli: niegodziwe). W efekcie obraz alternatywnego Orientu zostaje w $C \partial C$ wyostrzony do granic groteski (co w serii Red Alert nie tylko zauważono, ale i wykorzystano - stąd początkowo realistyczną poetykę zastąpił kamp).W świetle tych wniosków przynajmniej część aparatu pojęciowego, jaki wypracował postkolonializm (jak choćby pojęcie wiedzy konstruowanej), wydaje się użyteczna nie tylko w kontekście serii $C \odot C$, czego starałem się dowieść, ale i wielu innych RTS-ów, jakie wciąż czekają na opis z tej właśnie perspektywy. 


\section{Abstract}

\section{Szymon Piotr Kukulak}

JAGIELLONIAN UNIVERSITY (CRACOW)

Tanks of the Orient: Asia in the Strategies of Command \& Conquer in the Light of Postcolonial Theory

Kukulak proposes a postcolonial perspective to explore the portrayal of the Near and Far East in typical real-time strategy games of the last twenty-five years. He illustrates his argument with three alternative universes from seven games of the three subsections of the Command $\&$ Conquer cycle. In the games in question, five forces constitute the portrait of the virtual East, namely two fictitious terrorist organizations (modelled on real Islamic groups like the Hezbollah) as well as three alternative versions of twentiethcentury powers (Japan, the People's Republic of China and the Soviet Union). Kukulak examines the portrayal of the East as hostile to the West on three levels: the general aims of the Orient campaign (usually despicable), the tasks the player faces under his banner (usually immoral) and the arsenal used (usually cruel). The faithful representation of the latter contrasts with the paradoxical and syncretic nature of the ideology that the games described here ascribe to the East, based on loosely selected historical parallels and often on mutually exclusive stereotypes of the Orient.

\section{Keywords}

real-time strategy, postcolonialism, ethics 